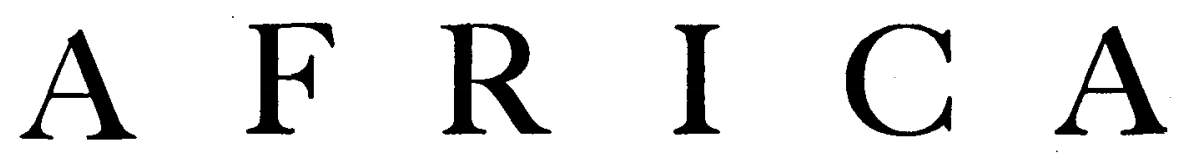

JOURNAL OF THE INTERNATIONAL AFRICAN INSTITUTE

\title{
ANTHROPOLOGY AND THE DEVELOPMENT OF AFRICAN STUDIES
}

\author{
THE TENTH LUGARD MEMORIAL LECTURE ${ }^{\Upsilon}$
}

\section{$D A R Y L L$ FORDE}

\section{Africa After the First World War}

THE foundation and the broad policies of our Institute emerged from what proved the First World War. The initial phase of modern economic advance in tropical Africa, following the introduction of the telegraph, railways, all-weather roads, was by the twenties making apparent a wide range of needs and opportunities for further progress in Africa-progress in which both the interests of, and contribution by, its peoples would be closely concerned. Within African territories the demand for literacy and training in new skills both more extensive and at higher levels was becoming more and more obvious and pressing. The significance of the increasing and inevitable association of Africans and their communities with a world economy was beginning to be more widely appreciated. With this growing recognition of the need for a more positive and constructive response many questions arose concerning not only the means of fostering such developments, but also their effects on the attitudes, beliefs, and institutions that had hitherto sustained the cultures and the social life of largely autonomous tribes and chiefdoms.

The increasing awareness among Africans, even in remote areas, of the wider economic and political world, into which they were being increasingly drawn through the external agencies of colonial administration, business enterprises, and overseas missions, was already seen by the percipient to call for action towards new goals. This was giving rise to discussions, among the still small numbers of Europeans with direct experience in, and concern for, African colonies, on such matters as the

I Delivered at University College London, on Monday, 19 June 1967 , during the annual meeting of the Executive Council of the International African Institute.

'Africa', the Journal of the International African Institute, is published by the Institute, but except where otherwise stated the writers of the articles are responsible for the opinions expressed Issued quarterly. (C) International African Institute, 1967. All rights reserved. 


\section{ANTHROPOLOGY AND THE DEVELOPMENT OF AFRICAN STUDIES}

means for developing local responsibility, to provide administrative experience, and lay foundations for more effective co-operation. It was also raising questions as to the possibilities and effects of efforts to replace a paternalism that sheltered indigenous institutions and outlooks by fostering economic and social changes in which Africans would look beyond the familiar world of tribal communities into an external milieu of western production, trade, and administration. To meet this prospect many proposals and experiments were being made and debated not only in metropolitan ministries, in the councils of colonial governments, and in the headquarters of church missions and business enterprises, but also among European officials in their stations and, more often than has been appreciated, with the Africans with whom they worked.

At the same time, and for the most part independently of the consideration of colonial problems, scholarly views of the significance of non-European cultures and social institutions as a field of study were responding to deep-seated changes. The gulf, so widely assumed in the nineteenth century to separate the 'savage' from the inheritors of Judean and Classical traditions, had by the twenties been questioned in many ways. And it had perhaps been most recently and pervasively undermined, not only in academic circles, by the ideological as well as the physical conflicts which emerged in the First World War and mocked so many assumptions concerning the superior achievements and destiny of Christian Europe.

And among those few scholars in ethnology, sociology, and psychology who had looked to the study of non-Western cultures and social institutions for a more general knowledge of mankind there were some for whom anxiety or distaste concerning the present conflicts and future prospects had reinforced interests in the exotic and reoriented their approach to the study of primitive peoples. Furthermore, in African as well as other overseas territories some administrators had been devoted to the study of the peoples they had been sent to govern. The works of such men as Delafosse, Monteil, Labouret, and others in French West Africa, Palmer, Arnett, Talbot, and Meek in Nigeria, Rattray in Ghana, and Johnston, Hobley, and Dundas in East Africa are lasting memorials to this great contribution. There was therefore in the twenties a growing appreciation that there was much to learn and make use of in the study of African peoples and that the means lay to hand in the development of ethnographical and other field-studies.

\section{The Founding of the Institute}

These various outlooks and promptings converged in the exchanges and discussions among colonial administrators, leaders of Christian missions, and anthropologists that led among other things to the founding of our Institute and contributed much common ground for its first programme.

In 1925 Hanns Vischer - who had begun his career as a C.M.S. missionary in Hausaland, had later served on Lugard's staff in the early days in Northern Nigeria, being especially responsible for educational policies, and was now an Adviser on Education to the British Colonial office-enlisted the active support of his former

I For a study of the early work and outlook of this Swiss-born, English educated pioneer see Sonia F. Graham, Government and Mission Education in Northern Nigeria 1900-1919, Ibadan University Press, I 966, which amplifies and in some respects modifies Dame Margery Perham's account in Lugard: the Years of Authority I898-1945, Collins, 1960. 
chief for a plan to establish an international organization which would promote research on African cultures and languages and secure its application to the tasks of educational and social advancement in Africa.

In the previous year, at the time of the American Phelps Stokes Education Commission to East Africa, a small international meeting of missionaries, scholars, and administrators had been held on the initiative of Hanns Vischer and Edwin Smith, who had had long missionary and educational experience in southern Africa, to consider what the latter presciently described as ' one of the major problems of our age ... the need for an application of scientific method to a solution of the questions arising generally from the contact of Western civilization with African culture . . . (being) convinced (that this) called for an advance in the education of the peoples of Africa through the medium of their own forms of thought' ${ }^{x}$ This meeting was followed by a conference in September 1925 which urged the establishment of an International Bureau to promote ' an understanding of African languages and social institutions with a view to their protection and use as instruments of education ' and to include the study of 'African Mental Culture'. ${ }^{2}$ From it developed the International Institute of African Languages and Cultures which was formally constituted on I July 1926 at the first and founding meeting of its governing body which represented twenty-six academic and other organizations from eleven countries.

The early programme and work of the Institute down to 1939 has been described by Edwin Smith and will be familiar to some of you, but I would like to recall today one major aspect, which has had a continuing importance both in its own development and in that of African studies, namely the reciprocal relations between these and progress of field research in social anthropology. Among those who enthusiastically welcomed the Institute's decision to concentrate a major part of its effort on promoting the study of ' what was happening to the structure of African society under the pressure of Western civilization', was Bronislaw Malinowski who had recently returned to London after his fortunate exile in the South Seas. He was early invited to join its Council and he wrote, in the Institute's new journal, in what was essentially a programme paper entitled Practical Anthropology, that 'If the Institute succeeds in creating this new branch of anthropology, the study of the diffusion of Western cultures among primitive peoples ... (it) will do a great service to anthropology and to the practical man as well '. 3

In the event, the convergence of interests which I referred to earlier found one of its most visible expressions in Malinowski's seminar in London in the thirties. To it went nearly all the young scholars, educators, and others who were awarded research fellowships and other grants by the Institute. Whether or not their earlier work had been in other disciplines they took part in it during their preparation for work in the field and often returned to it when working on their studies for publication. And their objectives were focused by the lively discussions on the analysis of primitive institutions, the explication of concepts expressed in native languages, the exploration of interrelations between diverse fields of indigenous activity and thought, and the impact on these of the new demands and opportunities presented by colonial administration, trading, wage eatning, and mission teaching. They were able to test

1 The Story of the Institute, Memorandum XII, 1934, pp. 1-2.
2 Ibid.

3 Africa, ii. I (r928), p. 37. 
ideas and approaches from their own previous studies against the provocative theses and questionings of Malinowski and the viewpoints of their fellows. Among them were Africans including the Sesutho scholar Z. K. Mathews and a young and lively student Jomo Kenyatta. There were mission teachers and administrators and several research workers who had come back after a period in the field often outside Africa to present their findings. As several early research fellows of the Institute have vividly conveyed to outsiders and to later generations of students, Malinowski is remembered by them not only for his remarkable ability for provoking a vigorous and spontaneous response to whatever was under discussion, including his own exposés of Trobriand ethnography or the blindness of other ethnologists. His readiness to challenge any formulation evoked a general atmosphere of constructive criticism with regard to the tasks that lay before the field research worker. It would, of course, be mistaken to regard Malinowski's seminar as having been developed only to fulfil one of the aspirations of the Institute. One could rather say that out of a happy conjunction and in a manner quite in accord with the theoretical views of its presiding genius, a 'function' was fulfilled $a d$ hoc by an 'institution'.

During these same years a group of French ethnographers under Marcel Griaule's leadership were also beginning to develop intensive field researches on rather different lines among the peoples of the Western Sudan. Here effort was concentrated on detailed recording of informants' statements to portray the complexity of thought and the elaboration of symbolism that was associated with every phase of the life and environment of these peoples. Deriving much of its inspiration from one aspect of Mauss's teaching in Paris these studies assumed rather than explored the vital part played by myth and ritual in sustaining social institutions. Marked by great empathy and calling for the respect of both scholars and administrators for the qualities of African thought and practical wisdom, these researches were, however, less concerned to analyse the underlying structure of social relations. Griaule and his colleagues do not appear to have exchanged ideas with those working under the auspices of the Institute at this time. While it is perhaps idle to speculate concerning the mutual stimulus that might have resulted it is a melancholy reflection on the width of the Channel and of the continuing Francophone-Anglophone communication gap in Africa. We can only regret that no dialogue was established between this group of French workers and social anthropologists in Britain during the thirties. But the value of the rich documentation provided by Griaule and his colleagues in further studies over the last twenty years is likely to be more widely appreciated with the recent revival of anthropological interest in the detailed analyses of categories of thought implicit in esoteric belief and ritual.

In France and French Africa at that time, there appears to have been less stress on ethnographic research for the important insights and valuable knowledge that it could provide on questions of administration, education, and economic development. It would seem that 'assimilationist' ideals for colonial peoples, which so greatly influence progressive expectations, was less favourable to the combination of practical and scholarly interests that occurred in Britain. But so far as the Institute was concerned the intention and the effort were international. Important as catalysts here were Christian missions from many countries that were active in Africa and many of whose leaders shared a concern for fostering self-development in the adaptations of 
African life to the advance of European commerce, industry, and thought. There was a wide acceptance among them that far from seeking to detach Africans from their own cultural backgrounds and societies, Western education should include positive action to sustain African traditions and to foster respect for them. It was in this connexion that research and assistance to promote the study of African languages and their use in education played so prominent a part in the early work of the Institute.

It would again be mistaken to suggest that there was anywhere a general, far less an overwhelming public sense of urgency concerning Africa in the thirties. Indeed many of those who were urging new policies or proposing the expansion of research sometimes felt as a dead weight the sense of tranquillity and achievement induced by the pacification and organization of territories in which it was expected that the development of trade and education could be securely pursued towards an ultimate but still remote goal of general modernization. Yet the positive achievements in the transformation had been considerable. By the standards of mid-nineteenth-century turmoils in tribal Africa the degree of order and progress was remarkable. There was a new freedom of movement. New remedies for ancient and hitherto fatalistically accepted ills were becoming available. There were new opportunities for wider experience, greater material rewards for the bold, and many small but significant and stimulating increments of comfort and new aspirations to be had by the many. In a few coastal centres in West and East Africa participation in overseas trade and Western education had already been long established, but elsewhere and despite such black spots as forced labour for plantations, the twentieth century had brought far greater security, considerable material advance, and new promise to a multitude of tribal peoples. It was with the cultural traditions and institutions of these peoples and of the new forms that would emerge under changing conditions that African studies were concerned. And, although blackwater, yellow fever, and less grave hazards were not yet a thing of the past, the opportunities for independent and systematic research were generally open for the first time.

It is, however, important to recall that forty years ago studies of the cultures and languages of African peoples were often regarded in academic circles, as well as by the educated public, as essentially fringe interests lying outside the main stream of Western scholarship. In general, too, the gap that was commonly seen to exist between traditional African societies and the concerns of Western industrial civiliza tion also limited interest in the ways and means whereby these tribal societies would be transformed and the forces that would be generated in colonial territories as they were increasingly brought within the economic and political orbit of the modern world. So far as doctrine and policy were concerned, there emerged two divergent trends of thought with regard to economic development and social advancement in Africa which affected the expectations and policies of metropolitan governments over a very wide field. And it is worth considering briefly here the connexion between these differences in outlook and the development of studies of African societies with which the Institute has been so closely concerned. What became known as the assimilationist view looked for advance through the progressive identification of African peoples with the civilization and institutions of the metropolitan country, by transplanting such institutions as were considered relevant including educational 


\section{ANTHROPOLOGY AND THE DEVELOPMENT OF AFRICAN STUDIES}

principles and forms, and creating élites in African territories whose models and sentiments would be European.

The other view, which became associated with the idea of trusteeship and in connexion with which Lugard introduced the term 'Dual Mandate', saw the opportunities and problems of African development more in terms of the immediate and local situation within a territory and among its diverse peoples. Less concerned with distant ends and perhaps less missionary in spirit with regard to Western civilization, it looked for continuity and adaptation in African institutions whereby these might develop, or wither where they became outmoded, in response to the changed political and economic conditions of the twentieth century. Hence tribal institutions together with the cultural values and customary law which sustained them were not to be lightly swept aside in the interests of economic advance, Western education, or more efficient administration. They should where possible be the vehicles for a largely spontaneous response to new opportunities.

As has often been pointed out these differing appraisals and sentiments on the part of Europeans and also of educated Africans, which underlay the approaches to so many specific questions concerning African affairs, did not necessarily manifest themselves in sharply opposed practice. On particular aspects and problems of administration assimilationist principles, on the one hand, and doctrines of 'indirect rule', on the other, were sometimes so extensively modified in the interests of more immediate objectives that both have sometimes been dismissed as colonialist myths. But, as social anthropologists never tire of demonstrating, myths have as a major rationale the expression and reinforcing of deep-seated attitudes towards social relations and cultural values. And, with regard to the scholarly study of the social life and cultures of the peoples of Africa, the differences in point of view and ultimate expectation of these two doctrines concerning long-term aims in colonial Africa have, as was suggested earlier, been very significant. As the climate of opinion and colonial policies in different countries veered one way or the other, interest and support for such studies changed both in degree and direction.

\section{Anthropological Studies in the Thirties}

Amid these various influences at work in the thirties, a generation of younger scholars-Fellows of the Institute and others who undertook intensive ethnographic researches in Africa-were able to devote themselves to the primary aim of coming to know a people as fully as possible in its own terms, of learning its many idioms by close participation in the daily life.

The old ethnography was rejected as seeking merely to record the occurrences and variation of particular cultural features or institutions over a smaller or larger region and to attempt broad and speculative reconstructions of their development and diffusion. It failed to explore their more immediate significance as part of an interlocking pattern that constituted and gave meaning to the total way of life in an actual society. But with this stress on interpreting activities and beliefs in terms of their meanings for those who participated in, and were affected by, them within the society, some suspect teleological assumptions could insinuate themselves. For this new focus of interest itself tended to ignore, if not to dismiss as irrelevant, the fact 
that any actual cultural configuration is always the momentary end-product of a complex historical process, of which the specific elements and conditions have vitally affected the forms and orientations of the activities, values, and institutions that it manifests. In short, stress on the significance, for understanding the contemporary social life of a people, of the meaning to them of the cultural patterns and institutions and the values sustaining these, often gave an impression of other, covert assumptions. The demonstration that the particular customs, beliefs, and values of a people did serve to satisfy in reasonable harmony an essential range of human needs, and thus to sustain a viable society, tended to be transposed into an implication that they had been devised to that end and were specifically indispensable. An analysis of effects was being seen as if it were a theory of causes.

Radcliffe-Brown, who came in the thirties to teach at Oxford and to resume his earlier interest in African societies, had been even more explicit than Malinowski in reacting against earlier approaches in anthropology. $\mathrm{He}$, too, castigated the earlier evolutionists for postulating a linear progress of societies, institutions, and ideas. Their assumptions were as inadequate and misguided as those of their opponents, the diffusionists who invented unverified world-wide migrations to account for formal similarities between remote cultures. Stigmatizing the views of both as conjectural, meaning spurious history he insisted, in his theoretical writings at least, that nonliterate societies, for which the availability of relevant documentary and other sources of reliable evidence as to their past was discounted, could and should be studied and understood only in terms of the present functions of their existing institutions. The meaning and significance of institutions and cultural patterns were to be sought in the contribution they made to maintaining the general structure and viability of a society. Valuable as this view could be as a working hypothesis for investigating their contemporary functions, it tended to become an exclusive doctrine, which diverted attention from evidence of dysfunction and of structural discordance in actual social life and so from the testing of the hypotheses themselves. The weakness lay not in requiring systematic analysis of structural relations and careful exploration of the discernible functions of particular features. Indeed these procedures have yielded striking results in many directions such as the analysis of the principles and implications of various forms of kinship organization, or of formulations and secondary elaborations in traditional idea systems and ritual symbolism. The defect consisted essentially in assuming that the attribution of functional significance constituted an explanation of structural forms-a misconception of the relation between structural and functional properties which had already been overcome in biology through the discrimination between mutation and adaptive selection as distinct processes in the development of life forms. This outlook militated against a concern with both longer-term process and the influence of external factors in the development of social institutions. The time perspective required for both of these tended to be excluded by the terms of a strictly synchronic structural-functional analysis. And this initially a historical bias tended to give an impression of both a stability and an inevitability of contemporary forms which inhibited inquiry into the contingent factors sustaining them and the particular conditions out of which they had developed. With the proper rejection of unsupported historical speculation, equilibrium models appropriate enough for the representation of short-term inter-relations among some 


\section{ANTHROPOLOGY AND THE DEVELOPMENT OF AFRICAN STUDIES}

cultural and structural elements often came to be regarded as the only proper tools of analysis. The discrepancies and the puzzles posed by anomalous features tended to be seen not as challenges that demanded assiduous inquiry but as secondary irregularities which could be put aside.

It would, however, be perverse to overstress the limitations of this frame of mind. The narrowing of perspective and the concentration on the close examination of existing social relations and values through directly observable data in their immediate context made it possible to break out of the often stereotyped and largely unanalysed categories of earlier ethnography, to discover detailed sociological processes which underlay and made viable what had often been superficially regarded as bizarre custom. Myths and rituals, status obligations, and transfers of wealth were all seen to have new meaning as part of a nexus in which they expressed a moral order, a code for a pattern of mutually adjusted norms that sanctioned both a structure of social relations and a system of values.

It has also to be borne in mind that any theoretical short-comings as to the explanatory status of functional studies have not detracted from the great value of an approach to field research which sought, through close participant observation and systematic recording, to portray the contemporary cultural and social life of a community, tribe, or chiefdom in action, and to analyse as structural elements the many patterns of social relations and ideas that ordered various parts of the social field. From it there developed a continuing critique of concepts and a refining of categories, as these became relevant to the many problems concerning cultural and social processes, which initiated, not only advances in field ethnography and anthropological theory in a narrower sense, but an interchange of conceptions and insights with other disciplines leading towards a common frame of description over a wider field of cultural and social studies.

\section{Growti of African Studies since the Second World War}

The Second World War brought African studies virtually to a standstill for over five years; but among its many consequences has been the great expansion of research on all aspects of social and cultural life in the African continent. In the immediately post-war years new centres for its development in universities and in special institutes were established in Africa as well as overseas. Public funds for research on a far greater scale were provided by the metropolitan governments soon to be followed by substantial grants from foundations especially in the U.S.A. Already in the fifties the resources in men and funds were many times greater than had existed before the war. Alongside the research in ethnography, linguistics, and administration that had been longer established, work in new fields and problems developed. Economic studies began to be pursued in connexion with the plans and problems of development. With the advance towards representative government and independence the attention of political scientists was directed first to constitutional developments and then to the growth of political parties and voting behaviour. Academic historians, especially those who had come to teach in the new universities in Africa, began to explore, often for the first time, the public and private archives. 
By the fifties, too, the first post-war generation of African scholars who had studied overseas after the war were making their research contributions to African studies. And from across the Atlantic the foundations were being laid by the field studies of a few American anthropologists, political scientists, and linguists for the veritable explosion of research and teaching programmes in African studies at universities in the United States.

This remarkable expansion is both too recent and too multifarious for definitive appraisal at this time. Nor can it even be characterized in a few sentences. But the developments that it has led to have transformed the dimensions of field research in Africa and closer at home it has been the rapidly and sometimes bewilderingly expanding environment in which our Institute has sought to continue to make its contribution. For those who have participated in the Institute's activities only more recently, it may be useful to recall, however briefly, some of these over the past twenty years. The enlarged prospects for African studies were already envisaged, if by no means clearly foreseen, when plans could again be considered for the resumption of the Institute's work towards the end of the war. The war had cut short its consideration of proposals for setting up an international clearing house and information centre for African studies along the lines proposed by Lord Hailey in his African Survey in 1938 . While so comprehensive a plan was not immediately feasible in the late forties, several projects which sought both to assist further research and to make its results more widely available were undertaken.

The Ethnographic Survey of Africa was begun in 1945 with initial grants for research assistance and publication from the British Colonial Development and Welfare Fund and subsequent co-operation and assistance from French and Belgian sources. This continuing project has been able, as it has progressed, to take advantage of a generation of post-war field research, and, while not yet completed, the fifty parts so far published have both afforded guides for further research and met the needs of a wide range of scholars and administrators and younger students entering the African field. A comparable scheme on somewhat different lines was organized to provide in the Handbook of African Languages a systematic guide to existing knowledge concerning the classification and distributions and demography of African languages and an international linguistic field research project was undertaken to survey the littleknown northern Bantu borderland zone across Africa.

A start was also made in 1945 towards building up at the Institute a threefold classified card catalogue of Africanist literature generally retrospective to the beginning of the century and cumulative to date. As well as being widely consulted and used to assist specific inquiries in a period of rapidly expanding interest this unique catalogue has provided the basis for the series of selective regional and special subject bibliographies that the Institute has been able to publish. In 1948 with the aid of initial grants from Unesco it was also able to establish an abstracts journal of current periodical literature. And African Abstracts has now in its eighteenth year been made still more widely useful by arrangements (in collaboration with Cardan) for publishing editions in both English and French.

With further grants from foundations and from Unesco the Institute was also able to contribute to the rapidly expanding opportunities for field research in the fifties. Over thirty fellowships and smaller grants have been provided since 1945, some of 


\section{ANTHROPOLOGY AND THE DEVELOPMENT OF AFRICAN STUDIES}

them in connexion with special projects which it had undertaken. It has also been able, through its Research and Publications Fund, to publish a considerable number of studies by its own Fellows and others. Some thirty field research monographs have been published in this way since 1945 .

When interest in African studies began to develop strongly in Unesco in the early fifties the Institute was able to assist its plans and to benefit from them. Thus facilities were provided for preparing and publishing in English and French the volume of studies on African Systems of Kinship and Marriage (I95I) and for field researches and a series of studies of African beliefs and social values published in African Worlds (1953). As successors to African Political Systems (1939), the importance and value of which only came to be fully appreciated after the war, these collections of studies brought together for a new generation of students a representative body of recent research. Unesco also gave its support for the first major review of research on the social effects of urbanization in tropical Africa. Preparatory studies, an interdisciplinary field study of Stanleyville (now Kisangani) Congo (195I-3) and a conference at Abidjan (1954) were organized by the Institute and followed by the volume of studies and reports in Social Effect of Industrialization and Urbanization in Tropical Africa (1957) published by Unesco in English and French.

In association with the International Missionary Council and the assistance of grants from the Carnegie Corporation and the British Colonial Development and Welfare Fund the Institute was also able to sponsor sociological, legal, and mission studies for a Survey of African Marriage and Family Life (1953).

More recently, with the generous support of the Ford Foundation, it has, as you will all know, been able to undertake a programme of annual International African Seminars beginning with Makerere in 1958 and of which the latest was held at Addis Ababa last year. Each has been held in an African university centre, bringing together a small group of specialists for an intensive review of a selected topic. The visiting and local participants and the African universities have generally expressed their appreciation of benefits derived from these meetings and the publication of the volumes of studies prepared for the seminars has made these reviews of recent advances in African studies generally available to scholars. It has, therefore, been encouraging to have had recerit confirmation that the Ford Foundation will continue grants for at least two further seminars.

In 1964, after nearly twenty years of development in African studies since the war, we were able to organize a stocktaking and review of prospects. The Conference held at Ibadan was attended by some eighty more senior Africanists concerned with a wide range of disciplines and responsible for research centres and teaching programmes both in Africa and overseas. The Institute itself is only one of the organizations that has derived benefit from the many discussions and recommendations that emerged during that busy week in Ibadan. But it will, I trust, continue to play its part in helping to meet some of the needs and opportunities to which the rapid development and diversification of African studies has given rise. It has already been able to respond to one of the recommendations made at the 1964 Conference, by enlisting the aid of the Ford Foundation for organizing a specialist conference on the development and co-ordination of Africanist bibliography to be held in Nairobi later this year. 


\section{Time Perspective in Anthropological Studies}

With the greatly increased body of research and reanalysis over the past twenty years the earlier dichotomy between functional studies of tribal institutions, on the one hand, and the study of political and economic developments in Africa, on the other, has been bridged from both directions. Anthropologically trained field-workers have appreciated that, with regard to many problems, description and analysis could not be realistically confined to attempts to isolate traditional institutions and social relations for what Malinowski in 1934 called 'the reconstruction task'. It has been recognized that even over the short term of a generation the impact of colonial government and external forces could induce pervasive changes in activities, values, and social relations. Indeed Malinowski himself after his visits to Africa in the thirties attempted a first analysis of this process of social change.

Earlier it had often been tacitly assumed that for the study of traditional institutions the more obvious and supposedly superficial effects of colonial rule and modern commerce or missions could be 'bracketed away' and discounted from the contemporary scene as being both generally remote from the daily concerns of the people and with little apparent influence on social structures and values. But this was often an illusion. The new sources of power and authority in the hands of officials, traders, and missionaries, both ' expatriate' and native, had limited and changed even when they had not replaced earlier forms. They had elicited new responses to the incentives and sanctions that they introduced. On the other hand, they had often eliminated conditions the effects of which were nevertheless still to be observed in social organization and values. To take but one striking instance, in many parts of tropical Africa pre-colonial political power had been linked to war, slave trading, raiding, and traffic in arms. And there were many social adjustments to this in such diverse fields as defensive settlement patterns, polygynous marriage, military organization, and external trade. Since many adjustments to, and other effects of war and spoliation continued to be reflected in aspects of social relations and cultural values, any attempt at a strictly synchronic interpretation was bound to be inadequate with reference to observations during the colonial period when hostilities had been severely circumscribed through the monopoly of force by an external power.

For some aspects of culture and social relations, such, for example, as ritual symbolism, kinship relations, or some aspects of the subsistence sectors of the economy, the presentation of an abstracted indigenous system might not introduce serious distortion in analysis or explanation. But even here, and still more seriously with regard to political institutions, an approach which placed methodological emphasis on the sufficiency and not merely the superiority of data directly observed by the field-worker among the people themselves had tended to weaken both description and explanation. A considerable and undetermined part of the data derived from the limited if not faulty reminiscent accounts of the old concerning events and conditions a generation or more ago and were to that extent a defective basis for describing an ' ethnographic present' which was in effect pre-colonial.

Thus the agents of government and external trade and Western education have been recognized as often crucial elements in the social field both past and present. Administrators, missionaries, and the managers of trading firms, with the particular 
policies and sanctions that they introduced, have, like the migration from tribal communities to new centres for work and trade, been important factors in a continually changing situation that called for analysis in developmental terms. Administratrative, missionary, and commercial records, as well as life histories have been explored as important sources for the study of these processes and for writing histories of particular aspects and sectors in the continental transformation of cultural and social life in twentieth-century Africa.

At the same time there has been further recognition that the colonial phase in Africa had not been imposed on a static past. The need for analysis in historical depth of the often extensive pre-colonial changes that had taken place in the cultures and social organization of many African peoples became apparent. Indeed some of these had been so considerable and pervasive and over so recent a period that the tribal cultures and political organizations directly available for ethnographic study could only be understood as comparatively recent transformations and sometimes disintegrations of very different patterns. Despite the belief by some that social anthropology rejected history and could not serve the historian, consideration of the studies being written in the fifties shows that synchronic functionalist doctrine and the association of anthropology with the study of 'peoples without history' found little reflection in actual research. In their field studies the attention of anthropologists and other social scientists was increasingly directed to oral traditions and local records as well as other evidence concerning the occurrence and causes of significant changes in the past.

Thus both the interests and the sources of anthropologists and historians have been growing together with regard to the recent past in Africa. While the former have been stimulated and assisted to explore archives, the potential value of which they had earlier been often unaware, the latter have come to appreciate that the interpretation of data in such sources often depends crucially on knowledge and understanding derived from field research concerning the character of the institutions to which the documents often refer in only oblique and distorted terms. Similarly it is beginning to be realized that the historian of an African people or region can often be sadly misled without a sophisticated anthropological critique in the use of oral tradition.

For the study of contemporary social changes the importance of time perspective is equally clear, since it is indispenable to relate the directly observable situation to the past not only to discover and evaluate the factors that have affected it but also to attempt to estimate their further consequences. In short it is not methodologically defensible or possible in practice, in studies of the institutions of African peoples, to dichotomize a pre-colonial 'ethnographic present' and a contemporary world of social change. Not only have these periods flowed into one another. The factors and processes operating in the past have left their mark on the cultural and social present. And the new forces of territorial administration-whether colonial or independent national - and of other external cultural and economic influences (missions, schools, and commerce) have already had manifold subtle effects on the outlook and social patterns which the field-worker is investigating.

This implies first that the perspective should be frankly diachronic, alert both to conditions and factors which, although now past, have contributed to the shaping of 
present attitudes and behaviour, and also to newly operative conditions and factors that are modifying these again. It also implies that the student of an African society should not limit attention to contemporary observation and oral tradition but should search assiduously for documentary and other evidence and use these as fully and as critically as his field notebooks.

Thus even when as a field-worker the social anthropologist is centrally concerned with the present structure of social relations as distinct from the writing of a history, the testing of hypotheses concerning these aspects of African and, indeed of all social life, requires consideration of all available sources of which the immediate field data are a most important but incomplete part. For, without a time perspective and evidence of particular developments, discrimination between that which may be ascribed to cyclical process and that which results from the intervention of new and specific factors may be impossible. That such an approach can be greatly rewarding has already been shown by a number of recent studies such as those of Barnes on the Ngoni, of M. G. Smith on Hausa-Fulani Zazzau, of Vansina on the Kuba, of G. I. Jones on the Oil Rivers States, and de Garine on the Massa.

\section{Anthropology and the other Social Sciences}

Some of the greatly increased interest and resources devoted to the other social sciences over the past twenty years have also contributed substantially to the development of African studies. The interests and skills of scholars in several disciplines have been added to those of the field ethnographer. There has been a search for new sources of data in many directions and for new modes of inquiry. Effective bridges of communication between anthropological field-workers and those approaching African problems with the interests and background of such disciplines as jurisprudence, economics, psychology, and political science have been built.

In developing concepts with which to analyse African institutions and cultural values anthropologists have often been compelled to criticize and discard categories and terminology derived from Western legal, political, and economic thought. Notions of status, ownership, and tenurial rights derived from Western jurisprudence, of obligation from European political philosophy, of processes of production and exchange in terms of classical economic theory, or of the character and contexts of religious belief from Christian theology are well-known instances. However well such external conceptions and terms might have served administrative purposes in a rough and ready way, disinterested research has shown them to mask and distort the complex and interlocking systems of rights, obligations, and beliefs whereby African peoples had adjusted their political, legal, and other relations to the ecological conditions and social values of largely closed communities with predominantly subsistence economies.

On the other hand, professional lawyers and economists as well as administrators had been initially orientated by their training to apply external values and objectives to their study of African problems and to thinking in terms of movement towards a modern framework in relation to which the traditional social modes and economic relations of African tribes and chiefdoms could appear to be largely irrelevant.

But more recent work both by anthropologists, on the one hand, and by lawyers and economists, on the other, has been marked by greater mutual comprehension. 
The legal and economic significance of indigenous and locally evolving institutions is now being more closely studied while the relevance for the field-worker both of some fundamental concepts and of recent modes of analysis in jurisprudence and economics are more widely appreciated. This convergence of theory in the study of particular situations has been well illustrated in the Institute's recent seminar on 'Concepts in African Law'.

The study of emergent political institutions in contemporary Africa is of special importance in view of the large number of detailed studies and also of more general interpretations that have appeared over the last few years. The coming to independence of many new African states, itself part of a wider movement of political change in the tropical world, has not only aroused a much greater public concern with African affairs. It has greatly stimulated the interest of political scientists and contributed in no small measure to the rethinking of basic principles of analysis-the viewing of political systems in a wider socio-cultural framework and the undertaking of intensive empirical research which called for studies in the field where much could be learned from the anthropologists.

Earlier differences in approach and problems of mutual comprehension between anthropologists and political scientists were due not merely to differences of scale and focus, the former being concerned with intensive studies of small units comprehended as totalities while the latter have been more concerned with particular constitutional issues and political relations on a national or international scale. For studies of modern government and politics in Africa have included meticulous and revealing analyses of local government and of political movements based on research in the field. And anthropologists have through comparative studies based on field researches--their own and others--thrown much light on processes involved in the transformation of political life in Africa, such as the role of traditional leaders and of ethnic loyalties in political parties.

The difficulties confronting mutual comprehension have lain rather in differences of approach which have their roots in distinct academic traditions. Most political scientists and other students of government have approached the modern African scene from a background of knowledge and interest in the development of Western institutions. Although aware of the specific economic and social forces involved in the long elaboration of the political philosophies and institutions of Western societies, they have nevertheless tended to make of the latter a yardstick for the assessment of needs, goals, and practicalities in emergent Africa. There has accordingly been a tendency to evaluate constitutional developments and to estimate the character and strength of political forces in terms of social categories and political norms that have been derived from the study of the mercantile and industrial societies of the Northern Hemisphere or of later developments and doctrines of state socialism. Successes and failures of constitutional arrangements, of political representation, and agreements have too often been seen in terms of Western standards and assumptions.

Social anthropology, on the other hand, has over the past forty years been progressively enfranchising itself from a procrustean bed of Eurocentric categories in the study of the institutions of pre-industrial societies outside the Western world. Although it has derived much from the thinking of European sociologists who have sought to 
penetrate behind the external forms of Western institutions, there has been a continuous effort to derive, as closely as possible from the experience of field research, concepts and categories by which the character and roots of political relations in such societies could be distinguished and analysed in directly relevant terms. The anthropological field-worker has accordingly tended to formulate his descriptions in somewhat specialized terms, falling victim sometimes, in an effort to avoid distortion, to an extensive use of vernacular terms the connotations and implications of which can be adequately grasped only by those who are willing to immerse themselves in the details of a monograph.

More important, however, in this connexion, is the orientation towards newly intrusive political and economic factors and their local expression in rapidly changing societies. At the level of the village community, the tribe, the chiefdom, and also of the residential areas of modern towns the field-worker necessarily sees the new institutional forms and relationships that are generated by colonial and more recently by national administrations or by commercial agencies, churches and political movements, in terms of the specific situations. These new agencies and motives are impinging on a pre-existing pattern of roles and statuses and on an older and still tenacious set of values. In this there is nothing unexpected or new. The understanding of earlier and comparable changes in Western societies has been obtained through similar attempts to discover and analyse in detail the impact of the new forces, the conflicts they have engendered, and the resolutions that have emerged. The point is, however, that the anthropologist is viewing social change in contemporary Africa-somewhat in the manner of the historian of some major phase of change in the social development of a European people-as a movement in which the 'present' still encapsulates deeply held values generated in the 'past' and is infused with partial and often discrepant aspirations for the 'future'. He does not see new modes of regulation and vehicles of authority only as a blueprint for a new world, but as expressions of new forces operating on an existing society through which policy makers, both internal as well as external to it, are providing new means which will be put to old as well as new uses. His models of political change are derived from analysis of the older and persisting structures and values as well as the newer forces and roles that are being introduced into the social world. But, since such models depend for their validity on patient observation and inquiry at what to others might seem a microscopic scale, to obtain the data and insights that are not to be found in political declarations, government reports, or other documentary sources, and sometimes relate individually to small and superficially insignificant groups, such studies can appear too particularistic and unsusceptible of generalization, as well as too demanding for those who would portray, interpret, and forecast the politcal development of modern Africa on a wider canvas.

Given the particular circumstances and limitations of scholarly and of public interest in modern Africa this discrepancy of scale and outlook is perhaps inevitable. On the one hand, there has been the small band of anthropologists and other social scientists who have, over the past two generations, undertaken intensive studies of contemporary African institutions among a few peoples and, on the other, a newly awakened public interest, barely a decade old, in the part that new African states may play on the international stage and on the means required and available to meet the 
growing aspirations of African peoples and their leaders. The contrast between this situation and the great range of academic studies as well as the governmental experience and resources that have been and are being devoted to the political life of the Western world could scarcely be more glaring. Both in Africa itself and outside it the need for the deployment of more adequate intellectual resources is only too evident.

But, in the meantime, it is important that, in making the best use of what we have and can get in the way of sound research on African politics, the dialogue-as it is now fashionable to call it--should be made more effective between social scientists engaged in detailed field research and the students as well as the educated public concerned with national and international affairs relating to Africa. This means that the intricate and sometimes conflicting processes, producing many diverse amalgams of old and new institutional patterns and social objectives, should not only be more closely studied in particular researches but also that their relevance to the understanding of the social and political realities of contemporary Africa should be more effectively conveyed to students of government and to publicists.

\section{Conclusion}

The focus of anthropological interest in Africa has continued to lie in the understanding of the indigenous and developing cultures and institutions of its peoples. It has responded to the imaginative and intellectual challenge presented by customs, conceptions, and patterns of social relations that were often not directly comprehensible within the conventional categories of Western thought and has first sought to analyse and interpret such societies in their own terms. The further attempt at presenting in other and universal language the folk modes of other cultures is itself part of a wider task. This is the more general advance in the social sciences in attempting to formulate concepts for the analysis of social interaction and conceptual thought that are generally applicable to the different aspects of human society. As the development of anthropological studies of particlar communities has shown, the semantic difficulties have been and will continue to be very great. For the student of another culture can bring initially to his study only the conceptual tools acquired in his own intellectual milieu and social experience. And it is only through continuous criticism, the re-evaluation of data, and the reformulation of concepts that it has been possible to achieve substantial emancipation from ethnocentric categories.

By their collegaues in other disciplines and still more by those involved in practical affairs and problems in Africa these objectives of anthropologists have on occasion been regarded as an esoteric specialization with which they could have little concern. But such a view is short-sighted. Not only has anthropological research contributed greatly to the development of sociological thought; it has also to be seen against the incomparably greater amount of detailed scholarship that lies behind behind informed understanding of the cultural and social life of Western peoples. It is on such understanding as it seeps through to the many sources of authoritative opinion that intelligent and balanced judgement in public affairs as well as intellectual standards and dispassionate attitudes of mind depend. One important factor underlying the political and economic instability of tropical Africa today is a continuing ignorance in responsible quarters concerning the social and cultural conditions and 
processes which govern the lives of its peoples. This unawareness of the many complex conditions and sentiments operative among different ethnic groups and occupational categories can be as serious within the new élites in Africa itself as among those outside Africa who are responsible for advice and decisions on policy.

This is not to suggest that the far-reaching technological, economic, and political changes which Africa is experiencing could or will, unlike other rapid cultural and social transformations, avoid all violent dislocations and the sometimes strident vociferations that accompany them. It is simply to assert that the relatively small human and material resources required for more effective achievement in African studies in the immediate future could, both within Africa and in the outside world, be immensely rewarding in terms of an increment in political wisdom and common understanding. And more specifically, this calls for the direction of more resources to fundamental and intensive research. For without this the plethora of generalized accounts and prognostications on African affairs that are now being published will often continue to be uncertain guides to the realities concerning the diversity of cultural values and social forces that are at work in the daily lives of African peoples today.

\section{Résumé}

\section{ANTHROPOLOGIE ET DÉVELOPPEMENT DES ÉTUDES AFRICANISTES}

L'INSTITUt International Africain à été fondé après la première guerre pour répondre à une heureuse conjonction d'intérêts résultant de la necessité croissante de donner une réponse constructive aux nouvelles exigences du développement économique et social en Afrique. Des missionnaires, des administrateurs coloniaux et des chefs d'entreprise, ainsi que les étudiants et intellectuels africains, ressentaient le besoin d'études universitaire désintéressées répondant aux questions résultant de la participation croissante des Africains à la vie économique moderne.

Les opinions sur les besoins de la recherche furent influencées par les divergences entre les aspirations at les espoirs du futur développement, ceux-ci allant de la perspective assimilationiste qui recherchait le progrès, depuis l'identification des intérêts africains et leur assimilation à ceux de la civilisation européenne, jusqu’à la perspective, plus avancé, consistant à fournir la réponse par les Africains eux-même, en sauvegardant leurs traditions dans le cadre d'un pouvoir colonial. C'est d'avantage en fonction de ce dernier point de vue que la recherche anthropologique s'est engagée dans le développement de l'education, le progrès économique et l'expérience politique à partir des modes de pensée et de l'organisation sociale des Africains.

Le développement des études anthropologiques a été, vers les années 30 , basé sur la compréhension et l'analyse d'un peuple, au moyen d'une observation étroite et directe, en termes d'analyse structurale et fonctionelle, qui devrait permettre aussi de comprendre les effets des institutions occidentales sur les sociétés africaines. Cette approche a entrainé un net progrès dans l'analyse des processus sociologiques et des valeurs culturelles qui y étaient impliqués, a donné un sens au mythe et au rituel, aux obligations du statut social et aux transferts de richesse. Cela a permis également une reformulation des concepts et catégories se rapportant a un plus vaste champ social et des études sociologiques sur le terrain. Mais, en même temps, cela a été une tentative pour suggérer le maintien des structures sociales, ne tenant pas compte du temps nécessaire à l'évaluation des facteurs externes et des processus à long terme impliqués le développement des institutions sociales.

Grâce à l'importance des études africanistes depuis la deuxième guerre mondiale, la recherche anthropologique a fait un bond en avant qui a permis d'établir des rapports plus 


\section{ANTHROPOLOGY AND THE DEVELOPMENT OF AFRICAN STUDIES}

étroits avec les autres disciplines des sciences sociales et de l'Histoire. Les études des institutions tribales et du développement économique et politique modernes ont été conduites parallèlement. Les influences multiples du pouvoir colonial et autres forces externes, ont été analysées en fonction du contexte social indigène et des réponses que ces influences ont entrainées. On a en même temps decouvert qu'il y avait eu de nombreux changements sociaux et culturels, avant comme pendant la période coloniale, qui étaient entièrement en rapport avec la connaissance des sociétés contemporaines africains. L'intérêt des anthropologues et historiens s'est simultanément developpé avec, d'une part, l'importance de le découverte de la recherche et de la critique des documents, et autres sources, y compris les traditions orales, pour expliquer le sens et les effets de développement dans un passé récent; d'autre part, l'importance de la recherche de terrain, selon les critères de la connaissance sociologique, pour la critique et l'interprétation des sources historiques, est devenue évidente.

On a vu se créer une convergence d'intérêts entre les anthropologues et ceux qu ont abordé les études africaines, venant de différentes disciplines, comme le Droit, les Sciences Économique et Politique. Les études anthropologiques ont souvent montré des concepts et des catégories appartenant à la pensée traditionnelle occidentale dans ces disciplines qui se sont trouvés dans une position non pertinente et même en opposition avec les institutions africaines. Les philosophies politiques qui se sont developpées dans le contexte des sociétés industrielles occidentales peuvent nous induire en erreur dans l'analyse des conditions presentes et des buts de l'Afrique en marche où les changements sociaux actuels sont profondément affectés par les anciennes structures indigènes des relations et des valeurs.

Avec l'indépendance récente de plusieurs nouveaux États africains et l'intérêt croissant que l'opinion publique porte aux affaires africaines, le besoin de renforcer les moyens de la recherche fondamentale en Afrique, se fait de plus en plus sentir. De la même façon, il est de plus en plus importante de communiquer, d'une manière plus effective, les résultats de ces recherches à tous ceux qui cherchent à comprendre les réalités sociales et politiques dans Afrique d'aujourd'hui. Et, sur ce plan, les études anthropologiques peuvent apporter une contribution indispensable à une meilleure appréciation du caractère et de la diversité des cultures et des institutions en développement qui, actuellement, gouvernent la vie des peuples africains.

\section{CONTRIBUTORS TO THIS NUMBER}

DARYLL FORDE. Professor of Anthropology in the University of London; Director of the International African Institute; author of Native Economies in Nigeria, Yakö Studies, etc., and numerous papers.

KENNETH LITTLE. Professor of Anthropology in the University of Edinburgh; author of The Mende of Sierra Leone, and numerous papers.

ANNE PRICE. Graduated in sociology in the Faculté des Lettres of the Sorbonne, Paris; formerly a research assistant in the Department of Social Anthropology, University of Edinburgh.

RODNEY NEEDHAM. Lecturer in Social Anthropology, University of Oxford; author of Structure and Sentiment (University of Chicago Press, 1962), and of numerous papers on prescriptive alliance, symbolism, and classification.

KIRSTEN ALNAES. Obtained her master's degree in social anthropology at the University of Oslo; after field-work among the Konzo lived in Rhodesia for six years; at present research associate at the University College of Dar es Salaam, where she is working on an analysis of Konzo ritual songs for a Ph.D. thesis.

LADISLAV HOLY. Research Fellow of the Institute for Ethnography and Folklore, Czechoslovak Academy of Sciences, Prague; carried out field-work in 1961 and 1965 among the Berti in Darfur. 